\title{
Sergi Mekânlarında
}

\section{Doğal ve Yapay Aydınlatma Biçimlerinin Ziyaretçi}

\section{Deneyimi ile Olan ilişkisinin irdelenmesi}

\author{
İlknur Türkseven Doğrusoy \\ Dokuz Eylül Üniversitesi \\ Mimarlık Fakültesi, Mimarlık Bölümü \\ Yasemin Oksel Ferraris \\ Yaşar Üniversitesi \\ Mimarlık Fakültesi, Mimarlık Bölümü
}

\section{Giriș}

Sergileme mekânlarında ışık ve aydınlatma tasarımı, ziyaretçinin görsel konforunu ve sergi deneyiminden haz almasını etkileyen en önemli çevresel bileşenlerden biridir. Eserler ve sergilendiği ortamla ziyaretçi/izleyici arasındaki diyaloğu başlatan görme işlevi için ışığın varllğı gerekmektedir. Ayrıca sergi mekânlarında ışığın niteliği ve niceliğii, ziyaretçiyle sergi arasındaki iletişimin gelişmesinde ve çeşitlenmesinde anahtar bir role sahiptir (Ajmat vd. 2011). Sergilenecek eserlerin mekânla uyum içerisinde olması, sergileme mekânlarının nitelikli ve etkin bir biçimde aydınlatılması, sergiye katılma, bakma, bilgi edinme, öğrenme gibi temel hedeflerin gerçekleşmesi açısından oldukça önemlidir. Sergi mekânı, sergi ve ziyaretçi/ izleyici ilişkisinde öne çıkan aydınlatma faktörü, mekân atmosferini etkileyerek ya da sergilenen esere ilgiyi yükselterek ziyaretçinin sergi deneyimini önemli ölçüde etkileyebilmektedir (Erbay 2011).

İnsan ve çevre ilişkilerini çözümleyen çalışmalar, kișilerin kendilerini saran çevreyi nasıl algıladıklarını ve tepki verdiklerini, bu algıyı etkileyen ve değiştiren çevresel ve davranışsal faktörleri araştırmışlardır (Mehrabian ve Russell 1974; Holahan1982; Russell ve Arkkelin 1995; Bell vd. 2001; Bechtel ve Churchman 2002; Gifford 2007;
Winkel vd. 2009). 1950'lerde aydınlatmanın görüş netliği, görsel alg1 ya da görsel konfor gibi daha çok işlevsel yönleri ile ilgili çalışmalar gerçekleştirilmiş (Boer ve Fisher 1978; Boyce 1981), aydınlatma unsurunu insan ve çevre ilişkisi bağlamında değerlendiren araştırmalar literatürdeki yerini daha çok 1970'lerden sonra almaya başlamıştır (Flynn 1977). Aydınlatmanın kullanıcı gereksinimleri, deneyim, duygular ve mekân atmosferi ile olan ilişkisi ise ağırlıka 1980'lerden sonra çalışılmaya başlanmıştır. Bu konu ile ilgili gerçekleştirilen güncel çalışmalarda, aydınlatmanın kullanıcının değerlendirme ve tercih gibi duygusal tepkileri açısından çözümlendiği dikkati çekmektedir (Van Erp 2008). Daha çok çevre psikolojisi alanında yapılan bu araştırmalarda genellikle yapay aydınlatma konusu değişik türdeki mekânlarda ele alınmıştır (Gifford 1988; Biner vd. 1989; Heerwagen 1990; Knez ve Kerz 2000; Durak vd. 2007, Flynn 1977; Mehrabian ve Russell 1974;

Manav ve Yener 1999). Doğal aydınlatmanın kullanıcı gereksinimleri ile olan ilişkisini inceleyen çalışmaların daha çok ofis ve kütüphane gibi 1şığın performans etkisinin öne geçtiği mekânlarda gerçekleştirildiği dikkati çekmektedir. (Doğrusoy ve Tureyen 2007; Doğrusoy 2002; Kılıç ve Hasırcı 2011).

Sergi mekânlarının aydınlatılmasında ziyaretçilerin sergi deneyimlerinin,
Öz

Bu çalıșmanın amacı, doğal ve yapay aydınlatma biçimlerine göre sergi deneyimi ile ilișkili olan mekân algısının nasıl değiștiğini anlamak ve kullanıcının aydınlatma tercihlerini belirleyerek, ziyaretçi/izleyici odaklı tasarım bilgisi oluşturmaktır. Gerçekleştirilen alan çalışmasında, doğal yolla aydınlatılan CerModern ile yapay yolla aydınlatılan Arkas Sanat Merkezi gözlem ve anket yoluyla incelenmiştir. Alan çalışmasında, farklı biçimlerde aydınlatılan sergi mekânlarında duygusal ve bilişsel algı farkı araştırılmış, kullanıcıların aydınlatma tercihleri ve bu tercihleri belirleyen nedenler sorgulanmıştır. Toplamda 260 kişiye uygulanan anket verilerinin sonuçları, mekân algısının duygusal ve bilișsel anlamda incelenen iki sergi mekânı arasında farklılaştığını ortaya koymuştur. Ziyaretçilerin aydınlatma tercihleri analiz edildiğinde tercihlerin, iki ve üç boyutlu eserlere göre değiştiği görülmüştür. Üç boyutlu eserler için, eserler kadar ona arka plan oluşturan hacmin, iki boyutlu eserler içinse duvar yüzeyinin aydınlatılmasının önemli olduğu saptanmıștır. Üç boyutlu eserlerin aydınlatılmasında en çok tercih edilen yapay aydınlatma biçimi homojen 1şık dağılımı sağlayan yayınık aydınlatma, doğal aydınlatma biçimi ise yanal aydınlatmadır. İki boyutlu eserlerde ise ağırlıklı olarak yapay aydınlatma biçimlerinden duvar aydınlatması ve yayınık aydınlatma türleri tercih edilmiştir.

\section{Abstract}

The aim of this study is to figure out the change in space perception related to exhibition experience with regard to natural and artificial lighting types and to determine lighting preferences of users to produce visitor/ spectator based design knowledge. In the conducted field study, naturally lighted CerModern and artificially lighted Arkas Art Center were examined with both observations and questionnaires. In the field study, the difference in affective and cognitive space perception was searched and lighting preferences of users and the reasons behind them were examined. The results of the questionnaire conducted by totally 260 people displayed that perceptions of the examined two exhibition spaces were differed from each other When the lighting preferences of visitors were analyzed, it was found out that lighting preferences changed with regard to two or three dimensional works. Lighting of both background space for three dimensional works and the wall ground for two dimensional works were found as important as the lighting of the works. The most preferred artificial and natural lighting types for three dimensional works was diffused lighting and side lighting. For two dimensional works, artificial lighting types of wall washing and diffused lighting were preferred. Anahtar Kelimeler:

Sergi mekânları, alan çalışması, sergi deneyimi, mekân algısı, aydınlatma tercihleri.

Keywords:

Exhibition spaces, field study, experience of exhibition, space perception, lighting preferences. 
gereksinimlerinin ve tercihlerinin dikkate alınması son derece önemlidir. Sergi mekânlarının aydınlatılması konusunu ziyaretçi gereksinimleri bağlamında irdeleyen bir takım çalışmalar mevcuttur (Kesner 1993; Kurtay vd. 2003). Ancak özellikle ülkemizde doğal ve yapay olmak üzere farklı aydınlatma türlerini, mekân algısı ve kullanıcı tercihleri ile olan ilişkisi bağlamında karşılaştırmalı olarak irdeleyen güncel bir çalışma gerçekleştirilmemiştir. Günümüzde müzecilik ve sergileme olanakları ile ilgili gelişmeler dikkate alındığında, doğal ışığın zararlı etkileri nedeniyle tercih edilmediği geleneksel yaklaşımın sorgulanması ve sergi mekânlarında aydınlatma tasarımına yol gösterebilecek ziyaretçi/izleyici odaklı güncel bilgilerin ortaya konulması önemlidir.

Downs ve Stea (1973), algılamada duygu ya da anlamla ilişkili olan affektif boyut ile hatırlama ve hafıza ile ilgili olan bilişsel (kognitif) boyutun birbirinden ayr1 ele alınması gerektiği üzerinde durmuştur. Ittelson ve arkadaşlarına (1974) göre ise alg1, duygusal ve bilişsel boyutların karş1lıklı etkileşimiyle bir bütün olarak kavranabilir. Bu araştırmada Ittelson'un (1974) bütünsel bakışı temel alınmış ve sergi deneyimi ile ilişkili olan mekân algısının, duygusal (affektif) ve bilişsel (kognitif) süreçlerin karşıllıklı etkileşimi sonucu belirlendiği kabul edilmiştir. Bu anlamda çalışmada farklı aydınlatma türlerinin sergi mekânının algılanma biçimini fiziksel bir bileşen olarak etkileyebileceği öngörülmektedir.

Tercihler, ziyaretçilerin ön bilgi, niyet ve tutumlarının önemli göstergelerinden birisidir. Ayrıca tercihler, tasarım sürecinde dikkate alınabilecek kullanıcı merkezli bilginin üretilmesinde tasarımcrya önemli ölçüde yol gösterici olmaktadır. Mahrebian ve Russell (1974) çevreye verilen duygusal tepkilerin o mekâna yaklaşma ya da uzaklaşma niyetini ve davranışını etkilediğini ileri sürmektedir. Bu anlamda sergileme mekânlarının kullanıcısını oluşturan ziyaretçilerin aydınlatma tercihlerinin belirlenmesi önem kazanmaktadır. Sonuç olarak ziyaretçinin, kendi gereksinimlerine yanıt veren, mekâna ilişkin duygusal tepkilerini olumlu yönde etkileyen, konforlu ve doğru aydınlatılmış bir sergileme ortamında sergi deneyiminden haz alabileceği, ziyaretini sürdürme ve yineleme niyeti oluşturabileceği ileri sürülebilir.

\section{Alan Calıșması}

Yukarıda açıklanan kuramsal çerçeve 1şığında bir alan çalışması gerçekleştirilmiştir. Gerçekleştirilen alan çalışmasında, sergi deneyimi ile ilişkili olan, ziyaretçilerin mekânsal algılama ve değerlendirme tepkileri ile aydınlatma tercihleri belirlenmiştir. Deneysel çalışmalar, fiziksel değişkenler ile verilen tepkiler arasındaki ilişkileri bulgular ve mekânsal deneyim bilgisini dışarıda bırakırken, gerçek fiziksel ortamlarda gerçekleştirilen alan çalışmaları, tasarım sürecine yön veren kullanıcı merkezli bilginin elde edilmesinde kolaylaştırıcı olmaktadır. Tasarımcı gerçek fiziksel ortamlarda çalıştığından, sergi deneyiminin bütünsel olarak ele alınması, karıştırıcı değişkenlerin olabildiğince kontrol edilmesi ve aydınlatmanın bu süreçteki rolünün bağlam içinde kavranmaya çalışılması en tutarlı ve güncel yoldur. Keza, son dönemlerde insan-çevre ilişkileri transaksiyonel yaklaşım olarak da adlandırılan çok yönlü, bütünsel, bağlam verilerini dikkate alan ve etkileşime dayalı bir bakış açısıyla çözümlenmeye çalışılmaktadır. (Bonnes \& Secchiaroli 1995)

\section{Örneklem}

Sergileme mekânları müzelerden, galerilere ve çağdaş sanat merkezlerine kadar uzanan aralıkta oldukça geniş bir inceleme alanı tanımlamaktadır. Bu araştırmada, sergi mekânı örneklemi, güncel bir gelişme olarak ortaya çıkan ve serginin yanı sıra farklı özellikte kamusal etkinliklerle de desteklenen çağdaş sanat merkezleri ile sınırlandırılmıştır. Türkiye'de literatürden erişilebilen sanat merkezleri incelendiğinde, doğal ve yapay aydınlatma biçimlerini tipik olarak yansıtan iki çalışma alanı belirlenmiştir. İnceleme alanlarından ilki doğal aydınlatma biçimini örnekleyen CerModern Sanatlar Merkezi (Resim 1), 


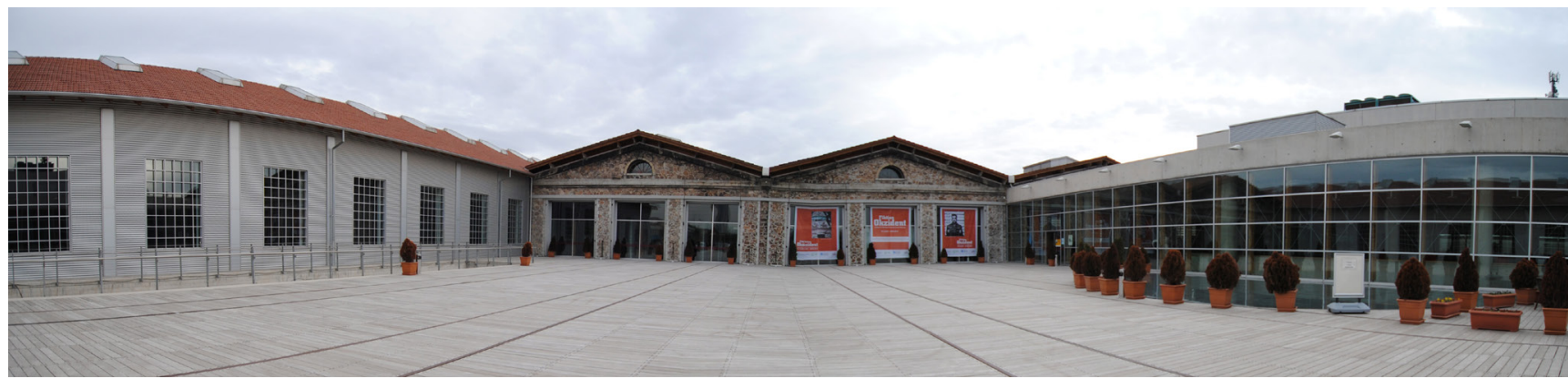

diğeri ise yapay aydınlatma biçimini örnekleyen Arkas Sanat Merkezidir (ASM) (Resim 2).

Eski bir cer atölyesinden dönüştürülen CerModern'de alan çalışmasının gerçekleştirildiği sergi mekânı binanın giriş katında yer almaktadır. Sergi mekânı tepe açıklığı ve yanal pencerelerden alınan gün ışığı ile aydınlatılmaktadır. Açık planlı sergi hacmi bölücü panolar aracılığ 1 ile gereksinime göre daha küçük sergi mekânlarına ayrılma olanağına sahip olup, iki boyutlu eserler için nötr bir sergileme yüzeyi sağlamaktadır. Yılın büyük bölümünde çeşitli etkinliklerin düzenlendiği CerModern'in bünyesinde konferans salonu, atölyeler ve açık/kapalı gösteri alanları yer almaktadır. 1877'de Fransa'ya tahsis edilen Fransız Konsolosluğu ile birlikte aynı binada yer alan Arkas Sanat Merkezi'nde (ASM) alan çalışmasının ger-

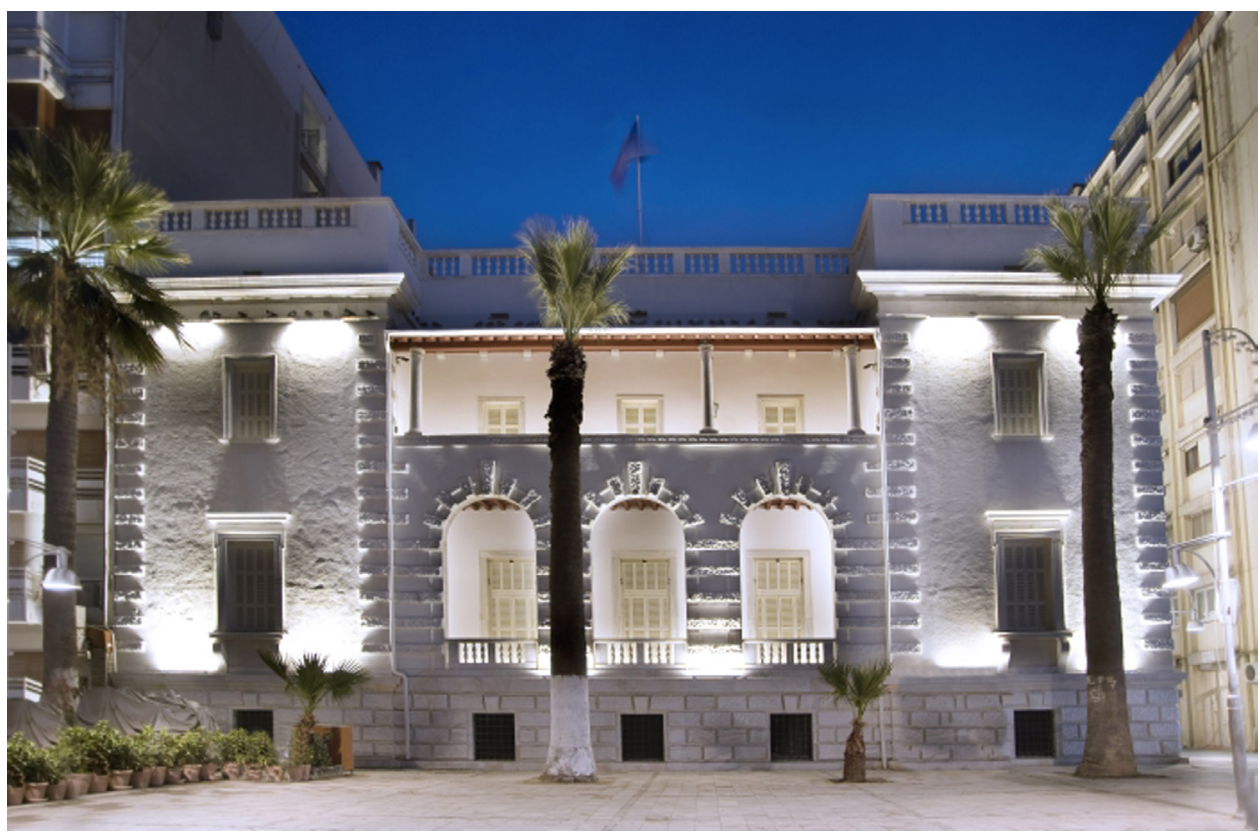

çekleştirildiği sergi mekânları ise yapının birinci ve ikinci katında yer almaktadır. ASM'nin sergi mekânlarında pencereler panjurlarla kapatılmış olup, oluşturulan 1şıklı panolar, CerModern'de olduğu gibi nötr bir sergi yüzeyi sağlamıştır. Arkas Sanat Merkezi'nde sergi dışındaki etkinliklere özgü tasarlanmış mekânlar yer almasa da yılın değişik zamanlarında atölye çalışmaları ve söyleşiler gerçekleştirilmektedir. Wineman ve Peponis (2003) iki tip sergi mekânından söz etmektedir. Bunlardan ilki açık planlı olup kullanıcıya tercih imkânı veren, diğeri ise izleyicinin hareketlerini ve seçimlerini belirleyen sergi mekânıdır. Bu anlamda CerModern ilk grupta, Arkas Sanat Merkezi ise ikinci grupta yer almaktadır.

\section{Yöntem}

Alan çalışması yöntemi olarak, gözlem ve anket tekniği kullanılmıştır. Yerinde

ve anket tekniği kullanilmistir. Yerinde 
yapılan gözlem ve incelemeler sonucunda inceleme alanlarının araştırma amaçları açısından uygunluğu ve fiziksel özellikleri incelenip tespit edilmiştir. Anket uygulamasına geçilmeden önce CerModern ve İstanbul Modern sanat merkezlerinde farklı yaş ve eğitim düzeylerinden 19 kişi ile pilot anket çalışması gerçekleştirilmiş ve anket ölçeği revize edilmiştir. Uygulamalardan ilki, doğal aydınlatma biçimini örnekleyen CerModern Sanat Merkezi'nde, 17-19 Aralık 2011 tarihleri arasında, mekânda sadece doğal aydınlatmanın etkin olduğu sabah ve öğlen saatlerinde, tesadüfî örnekleme yöntemi ile belirlenen 127 kişilik ziyaretçi grubuna uygulanmıştır. Eksik, tutarsız ya da ciddiyetsiz yanıtlandığı tespit edilen 27 katılımcı değerlendirme dışı bırakılmıştır. İkinci uygulama, yapay aydınlatma örneklemi olan ASM'de, 16-30 Nisan 2012 tarihleri arasında 212 kişiye uygulanmıştır. Yukarıda bahsedilen benzer nedenlerden dolayı 52 katılımcının tepkileri değerlendirme dışı bırakılmıştır. ASM'de değerlendirme kapsamına alınmayan tepkilerin önemli bir bölümü anket uygulaması sırasında oluşan elektrik kesintisi nedeni ile uygulamanın yarım kalmış olmasından kaynaklanmaktadır. Böylece CerModern'de 100, ASM'de 160 kişinin tepkileri değerlendirilmiştir.

Anketin ilk bölümünde ziyaretçi/izleyici profilini belirlemek üzere, cinsiyet, yaş, meslek gibi değişkenleri ölçmeye dönük sorular yöneltilmiştir. Mekân algısının duygusal (affektif) boyutunu ölçmek üzere ziyaretçilere, Kuller'in (1973) modelinden uyarlanan ve 15 adet bipolar sıfat çiftinden oluşan anlamsal farklilaşma cetveli uygulanmıştır. Mekân algısının bilişsel (kognitif) yani hatırlama ve hafiza ile ilgili olan boyutunu ölçmek üzere katılımcılara sergi deneyimlerinden akıllarında kalan ilk üç şeyi belirtmeleri istenmiştir. Ziyaretçilerin aydınlatma tercihlerini belirlemek üzere görsel bir ölçek geliştirilmiş ve aydınlatma tercihlerinin nedenlerini belirtmeleri istenmiştir. İstatistik analizler SPSS İstatistik 15.0 Evaluation Version program1 ile bilgisayar ortamında gerçekleştirilmiştir. Verilere uygulanan güvenirlik testleri sonucunda $\alpha$ değerinin 0,80 'in üzerinde olması, alg1 ve tercihleri ölçmek üzere geliştirilen anketin oldukça güvenilir olduğunu ortaya koymuştur $(\alpha=0,84)$.

\section{Bulgular}

\section{Ziyaretçi Profili}

Cinsiyet değişkeni dikkate alındığında ASM'deki kadın izleyicilerinin oranının CerModern'dekilere göre anlamlı düzeyde daha yüksek olduğu dikkati çekmektedir. Yaş değişkenine göre dağılımlar dikkate alındığında ise her iki sanat merkezini de ağırlıkta gençlerin kullandığı ve ziyaretçilerin yaş dağılımları arasında önemli bir farkın olmadığg görülmektedir. Meslek dağılımlarına bakıldığında, her iki grupta da sanat merkezi ziyaretçilerinin, çoğunlukla sanatla ilgisi olmayan mesleklerde çalıştığı ve bu oranın CerModern'de az farkla daha yüksek olduğu görülmüştür. ASM'yi kullanan öğrencilerin oranı ise CerModern'e göre daha yüksektir (Tablo 1).

\section{Mekânsal Algılama ve Değerlendirme}

$\mathrm{Bu}$ araştırmada mekânsal algının duygusal boyutunu ölçek üzere Küller’in (1973)

\footnotetext{
Tablo: I

Katılımciların sosyo-demografik özellikleri
}

Cinsiyet Yaş

\begin{tabular}{|c|c|c|c|c|c|c|c|}
\hline CERMODERN (N:100) & Kadın & Erkek & $15-24$ & $25-34$ & $35-44$ & 44-54 & $55+$ \\
\hline $\mathrm{N}$ & 45 & 55 & 25 & 21 & 18 & 15 & 21 \\
\hline $\mathrm{N}(\%)$ & $45,0 \%$ & $55,0 \%$ & $25 \%$ & $21,0 \%$ & $18,0 \%$ & $15,0 \%$ & $21 \%$ \\
\hline \multicolumn{8}{|l|}{ ASM (N:160) } \\
\hline $\mathrm{N}$ & 101 & 59 & 51 & 18 & 23 & 24 & 44 \\
\hline \multirow[t]{2}{*}{$\mathrm{N}(\%)$} & $63,1 \%$ & $36,9 \%$ & $31,9 \%$ & $11,3 \%$ & $14,4 \%$ & $15,0 \%$ & $27,5 \%$ \\
\hline & \multicolumn{7}{|c|}{ Meslek } \\
\hline CerModern (N:100) & Öğrenci & \multicolumn{2}{|c|}{ Emekli } & \multicolumn{2}{|c|}{ Sanatla ilgili } & \multicolumn{2}{|c|}{ Sanatla ilgisiz } \\
\hline $\mathrm{N}$ & 18 & \multicolumn{2}{|c|}{9} & \multicolumn{2}{|c|}{23} & \multicolumn{2}{|c|}{47} \\
\hline $\mathrm{N}(\%)$ & $18,0 \%$ & \multicolumn{2}{|c|}{$9 \%$} & \multicolumn{2}{|c|}{$23 \%$} & \multicolumn{2}{|c|}{$47 \%$} \\
\hline \multicolumn{8}{|l|}{ ASM (N:160) } \\
\hline $\mathrm{N}$ & 46 & \multicolumn{2}{|c|}{17} & \multicolumn{2}{|c|}{19} & \multicolumn{2}{|c|}{63} \\
\hline $\mathrm{N}(\%)$ & $28,8 \%$ & \multicolumn{2}{|c|}{$10,6 \%$} & \multicolumn{2}{|c|}{$11,9 \%$} & \multicolumn{2}{|c|}{$39,4 \%$} \\
\hline
\end{tabular}


mekânsal algılama ve değerlendirme ölçeği referans alınmış ve 15 sıfat çiftinden oluşan bir ölçek geliştirilmiştir. Pilot anket uygulamasindan sonra revize edilen ölçeğe faktör analizi uygulanmış, iç tutarlılığa katkısı olmaması nedeni ile "işlevine uygun-uygun değil", "sıradan-s1radışı" "rehavete yol açıcı-canlandırıcı" ve "sıcak-soğuk" sıfat çiftleri ölçekten çıkarılmıştır. Ölçeğe verilen tepkiler analiz edildiğinde, doğal aydınlatma türünü temsil eden CerModern sergi mekânlarının, ASM'ninkinden daha büyük, daha geniş, daha açık ve daha ferah değerlendirildiği görülmüştür (Şekil 1-4). Uyumlu-uyumsuz ölçeğine göre ise ASM'nin sergi mekânlarını çok uyumlu değerlendirenlerin yüzdesi CerModern'e göre az farkla daha yüksek olsa da, aralarında anlamlı bir fark olmadığı görülebilir (Şekil 5).

Mekânın fiziksel özelliğine vurgu yapan sıfat çiftleri arasında aydınlatma faktörü ile ilişkili olanların dağılımlarına bakıldığında CerModern'in sergi mekânlarını çok aydınlık bulanların oranının Arkas Sanat Merkezindekilere göre daha yüksek olduğu görülür (CerModern \%62, ASM\%47,5). Ancak ASM kullanıcılarından sergi mekânını aydınlık değerlendirenlerin yüzdesi CerModern'e göre daha yüksektir. Ayrıca ASM kullanıcılarından sergi mekânlarını karanlık ve çok karanlık olarak değerlendirenlerin oranı CerModern'e göre anlamlı düzeyde fazla değildir. Aydınlık düzeyi, ferahlık, genişlik ve büyüklük algıları birbiriyle ilişkilidir (İmamoğlu, 1975). Aydınlatma türü farklılığının mekânın aydınlık-karanlık değerlendirmesinde etkin bir fark yaratmadığı anlaşılmaktadır. Parlaklık matlık ölçeğine göre Cer Modern kullanıcılarından sergi mekanlarını parlak olarak değerlendirenlerin oranının (\%27), Arkas Sanat Merkezi kullanıcılarına göre daha düşük olmas1 $(\% 38,8)$, gerekli teknik önlemler alınmadığında yapay ışığın rahatsız edici parlama etkisinin doğal aydınlatmanın önüne geçebildiğini, bu konuda aydınlatma türünden çok aydınlatma tasarımının önemli olduğunu göstermektedir (Şekil 6,7).

Her iki sanat merkezinde çok hoş (CerModern \%55, ASM\%58,1), çok çekici
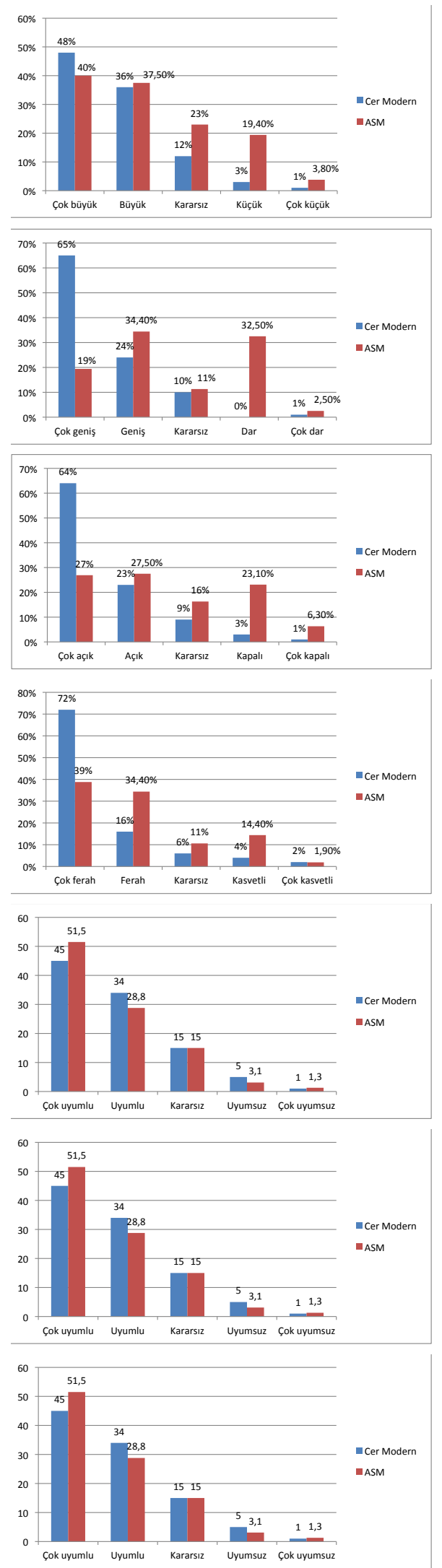

Şekil: 7

sergi mekânlarının parlaklık-matlık ölseğine göre değerlendirmesi.
Şekil: I
Sergi mekânlarının büyüklük-küçüklük
ölseğine göre değerlendirilmesi

ölseğine göre değerlendirilmesi

Şekil: 2

sergi mekânlarının genişlik-darlık

Şekil: 3

sergi mekânlarının açılık-kapalıık ölçeğine göre değerlendirilmesi

Şekil: 4

sergi mekânlarının ferahlık-kasuetlilik ölşğine göre değerlendirilmesi

Şekil: 5

sergi mekânlarının uyumluluk-uyumsuzluk ölçeğine göre değerlendirilmesi

Şekil: 6

Sergi mekânlarının aydınlık-karanlık ölşeğine göre değerlendirmesi. ölçeğine göre değerlendirilmesi 
(CerModern \%43, ASM\%54,4), çok güzel (CerModern \%56, ASM \%63,8) ve çok konforlu (CerModern \%46, ASM\%46) değerlendirmeleri birbirine yakın dağılımlar göstermektedir. Bu anlamda bu araştırmada sözü edilen sıfat çiftleri açısından aydınlatma türünün önemli bir fark yaratmadığı görülmüştür.

Alan çalışmasında mekân algısının bilişsel boyutunu ölçmek üzere katılımcılara sergi deneyimi sonrasında hafizalarında kalan ilk üç şey sorulmuştur. Açık uçlu olarak alınan tepkilere içerik analizi uygulanmış ve tepkiler üç grupta sınıflandırılmıştır. Bu gruplar, yapının sosyal / yardımcı mekânlarını, konumunu, fiziksel özelliklerini ve mekân örgütlenmesini içeren makro çevre, aydınlatma biçimini, sergi mekânını ve sergi ile ilgili detayları kapsayan mikro çevre ve sergi içeriğinin ya da sergi mekânının ziyaretçi üzerinde uyandırdığı duyguları kapsayan affektif deneyim olarak belirlenmiştir. CerModern'den ayrılan ziyaretçiler ilk sırada en çok makro çevreyle ilgili özellikleri hatırlarken (\%35), ASM ziyaretçileri en çok sergi mekânı, sergileme ve aydınlatma ile ilgili detayları içeren mikro çevre özelliklerini hatırlamışlardır. Affektif deneyimler arasında ise fark görülmemiştir. Her iki ziyaretçi grubunun \%34'ü yapının ya da serginin kendilerinde uyandırdığı duyguları kapsayan affektif deneyimlerini hatırlamışlardır.

CerModern'i kullanan ziyaretçilerin algısı makro çevre, mikro çevre ve affektif deneyimle ilgili bileșenler açısından daha dengeli bir dağ 1 lım gösterirken, ASM'deki ziyaretçilerin yarıya yakını mikro çevreye yoğunlaşmıştır. Kategoriler arasında yapılan chi-square testinde ilk sırada hatırlanan değişkenlere göre istatistiksel olarak anlamlı bir farklılaşma görülmüştür $(p<0,001)$. Ortaya çıkan bu farklılık, CerModern'in ASM'ye göre daha büyük olması, değişik nitelikte kamusal mekânlar içermesi, açık bir sergileme mekânı sunması ile ilişkili olabileceği gibi, mekânda görece homojen bir dağılım sağlayan doğal aydınlatma biçimiyle de açıklanabilir. ASM ziyaretçileri, yapının küçük ölçeği, hücresel sergileme ha- cimleri ve eserlere odaklanma sağlayan yapay aydınlatma sistemi ile mikro çevre özelliklerini daha fazla hatırlamış görünmektedirler. Ziyaretçilere sergi ile ilgili belleklerinde kalanlar sorulduğunda ise yapay aydınlatma sistemiyle aydınlatılan ASM'de sergi mekânın aydınlatmasıyla ilgili detayları hatırlayan ziyaretçi yüzdesi $\% 20$ olup, CerModern'inkinden daha fazladır (\%7). Serginin içeriği, hissettirdikleri ve sergi mekânı ile ilgili önemli bir fark oluşmazken, aydınlatma ile ilgili hatırlanan detaylar açısından iki sergi mekânı arasında anlamlı fark oluşması $(p<.005)$, aydınlatma biçiminin bilişsel algıda etkin olabileceğini göstermektedir.

\section{Aydinlatma Tercihleri}

Tercih ölçeği iki ve üç boyutlu elemanların sergilenmesinde literatürde en sık rastlanan aydınlatma türlerinin görselleştirilmesiyle hazırlanmıştır. Buna göre doğal aydınlatma biçimlerini örnekleyen tepe aydınlatması ve yanal aydınlatma, yapay aydınlatma biçimlerini örnekleyen yayınık aydınlatma, spot aydınlatma ve duvar aydınlatması olmak üzere beş farklı aydınlatma biçimi belirlenmiştir. Aydınlatma seçenekleri 10 metre genişliğinde ve 4,8 metre yüksekliğinde dikdörtgen formlu bir mekânda Google SketchUp Pro 7, Autodesk 3Ds Max ve Vrayplug-ini programları kullanılarak modellenmiştir. Geliştirilen görsel modelde yanal aydınlatma için kullanılan pencere açıklığ 4 metre yüksekliğinde ve 7 metre genişliğinde, tepe açıklığ ise 2,5 metre genişliğinde ve 7 metre uzunluğundadır. Duvar aydınlatması için kullanılan halojen lambaların fiziksel özelliklerine sahip ışık kaynağ tirilerek sergileme duvarını aydınlatacak şekilde ayarlanmıştır. Spot aydınlatma da aynı biçimde tabloyu aydınlatacak şekilde $50 \mathrm{~cm}$ uzakta yerleştirilmiştir. Aydınlatma seçenekleri sergilenen objeden 2 metre uzaklıkta olacak şekilde $25 \mathrm{~mm}$ kamera kullanılarak görselleştirilmiştir. Tepkiler analiz edildiğinde, üç boyutlu eserlerin aydınlatılmasında, her iki grup toplamında ziyaretçilerin yapay aydınlatma türevlerinden biri olan yayınık aydınlatmayı (\%35) 


\begin{tabular}{|c|c|c|c|c|c|c|c|c|c|c|}
\hline AYD. TÜRÜ & \multicolumn{4}{|c|}{ DOĞAL AYDINLATMA } & \multicolumn{4}{|c|}{ YAPAY AYDINLATMA } & & \\
\hline \multicolumn{11}{|c|}{$\begin{array}{c}\text { AYDINLATMA } \\
\text { ŞEKLI }\end{array}$} \\
\hline & \multicolumn{2}{|c|}{$\begin{array}{c}\text { YANAL } \\
\text { AYDINLATMA }\end{array}$} & \multicolumn{2}{|c|}{$\begin{array}{c}\text { TEPE } \\
\text { AYDINLATMASI }\end{array}$} & \multicolumn{2}{|c|}{$\begin{array}{c}\text { YAYINIK } \\
\text { AYDINLATMA }\end{array}$} & \multicolumn{2}{|c|}{ SPOT AYDINLATMA } & \multicolumn{2}{|c|}{ TOPLAM } \\
\hline $\begin{array}{l}\text { TERCiH } \\
\text { YÜZZDESİ }\end{array}$ & SAYI & $\%$ & SAYl & $\%$ & SAYI & $\%$ & SAYI & $\%$ & SAYI & $\%$ \\
\hline CER & 37 & 37 & 7 & 7 & 28 & 28 & 28 & 28 & 100 & 100 \\
\hline ASM & 48 & 30 & 10 & 6,3 & 63 & 39,4 & 39 & 24,4 & 160 & 100 \\
\hline TOPLAM & 85 & 32,7 & 17 & 6,5 & 91 & 35 & 67 & 25,8 & 260 & 100 \\
\hline
\end{tabular}

\begin{tabular}{|c|c|c|c|c|c|c|c|c|c|c|c|c|}
\hline AYD. TÜRÜ & \multicolumn{4}{|c|}{ DOĞAL AYDINLATMA } & \multicolumn{6}{|c|}{ YAPAY AYDINLATMA } & & \\
\hline & \multicolumn{2}{|c|}{$\begin{array}{c}\text { YANAL } \\
\text { AYDINLATMA }\end{array}$} & \multicolumn{2}{|c|}{ TEPE AYDINLATMASI } & \multicolumn{2}{|c|}{$\begin{array}{c}\text { YAYINIK } \\
\text { AYDINLATMA }\end{array}$} & \multicolumn{2}{|c|}{$\begin{array}{c}\text { DUVAR } \\
\text { AYDINLATMASI }\end{array}$} & \multicolumn{2}{|c|}{ SPOT AYDINLATMA } & \multicolumn{2}{|c|}{ TOPLAM } \\
\hline $\begin{array}{l}\text { TERCiH } \\
\text { YÜZDESI }\end{array}$ & SAYI & $\%$ & SAYI & $\%$ & SAYI & $\%$ & SAYI & $\%$ & SAYI & $\%$ & SAYI & $\%$ \\
\hline CER & 19 & 19 & 2 & 2 & 17 & 17 & 61 & 61 & 1 & 1 & 100 & 100 \\
\hline ASM & 22 & 13,8 & 3 & 1,9 & 36 & 22,5 & 93 & 58,1 & 6 & 3,8 & 160 & 100 \\
\hline TOPLAM & 41 & 15,8 & 5 & 1,9 & 53 & 20,4 & 154 & 59,2 & 7 & 2,7 & 260 & 100 \\
\hline
\end{tabular}

\begin{tabular}{|c|c|c|c|c|}
\hline \multirow{2}{*}{ AYDINLATMA ŞEKLi } & \multirow{2}{*}{\multicolumn{2}{|c|}{ TERCIH NEDENI }} & \multicolumn{2}{|c|}{ TERCIH YÜZDESI } \\
\hline & & & SAYI & $\%$ \\
\hline$\$$ & $\begin{array}{l}\begin{array}{c}\text { mekanin algısina } \\
\text { ilisgin }\end{array} \\
\text { (n) }\end{array}$ & Mekanın ferah ve aydınlık olması & 49 & 52,7 \\
\hline 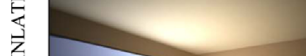 & $\begin{array}{c}\text { obje-mekan } \\
\text { iliş̧isine iliş̧kin }\end{array}$ & Objenin mekandan kopmadan algılanabilmesi & 8 & 8,6 \\
\hline Е્र & \multirow{3}{*}{$\begin{array}{l}\text { obje algısıma } \\
\text { iliş̧kin }\end{array}$} & Objenin daha doğal algılanması & 23 & 24,7 \\
\hline $\overrightarrow{\mathrm{K}}$ & & Objenin algısını kolaylaştırması & 13 & 14,0 \\
\hline & & TOPLAM & 93 & 100,0 \\
\hline$\overline{2}$ & $\begin{array}{l}\text { obje-mekan } \\
\text { ilişkisine ilişkin }\end{array}$ & $\begin{array}{l}\text { Objenin bulunduğu ortamla manzara faktörü olmadan uyum } \\
\text { içerisinde olması }\end{array}$ & 2 & 18,2 \\
\hline 崖 & \multirow{3}{*}{$\begin{array}{l}\text { obje algısıma } \\
\text { ilişkkin }\end{array}$} & Objenin ön plana çıkması & 4 & 36,4 \\
\hline 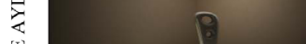 & & Objenin daha doğal algılanması & 5 & 45,5 \\
\hline 产 & & TOPLAM & 11 & 100,0 \\
\hline \multirow{4}{*}{$\begin{array}{r}0.0 \\
\frac{0}{2} \\
2 \\
2\end{array}$} & \multirow{2}{*}{$\begin{array}{l}\text { obje-mekan } \\
\text { ilişkisine ilişkin }\end{array}$} & Obje ve sergi alanının birlikte homojen olarak aydinlatılması & 2 & 5,6 \\
\hline & & $\begin{array}{l}\text { Objenin dıss dünyadan kopartılarak mekan ile beraber } \\
\text { algilanması }\end{array}$ & 18 & 50,0 \\
\hline & \multirow[t]{2}{*}{$\begin{array}{c}\text { obje algısına } \\
\text { illişin }\end{array}$} & Objenin ön plana çıkarılarak ayrıntıların okunabilmesi & 16 & 44,4 \\
\hline & & TOPLAM & 36 & 100,0 \\
\hline 育 & $\begin{array}{l}\text { obje-mekan } \\
\text { iliş̧isine ilişkin }\end{array}$ & $\begin{array}{l}\text { Cevre ile bağlantısııı kopartarak objenin mekandan } \\
\text { bağımısız olarak algılanmasısı sağlaması }\end{array}$ & 8 & 12,3 \\
\hline $\overrightarrow{\mathrm{Z}}$ & \multirow{3}{*}{$\begin{array}{l}\text { obje algısına } \\
\text { ilişkin }\end{array}$} & Objenin vermek istediği anlamı ortaya çıkması & 34 & 52,3 \\
\hline$\underset{\xi}{E}$ & & Obje üzerinde vurgu yapılarak odaklanma sağlanması & 23 & 35,4 \\
\hline ڤे & & TOPLAM & 65 & 100,0 \\
\hline
\end{tabular}

çoğunlukla tercih ettiği görülmektedir.

Bu tercihi az farkla sergileme mekânları için çok yaygın olmayan doğal aydınlatma türevi olan yanal aydınlatmanın $(\% 32,7)$, daha sonra spot aydınlatmanın izlediğ $i$ $(\% 25,8)$, en az tercih edilen aydinlatma türünün ise tepe aydınlatması olduğu (\% 6,5) görülmektedir (Tablo 2).

İki boyutlu eserler için yapılan aydınlatma tercihlerinin üç boyutlu eserlere göre farklılık gösterdiği görülmektedir.
Tablo: 2

Ü̧ boyutlu eserlerin aydınlatma tercihlerinin dağılımı

Tablo: 3

iki boyutlu eserlerin aydinlatma tercihlerinin dağılımı

Tablo: 4

$\ddot{U}_{\zeta}$ boyutlu eserlerin aydınlatma tercihlerini etkileyen nedenlerin dağılımları. 
Tablo: 5

iki boyutlu objelerin aydinlatma tercihlerini belirleyen nedenlerin dağılımları

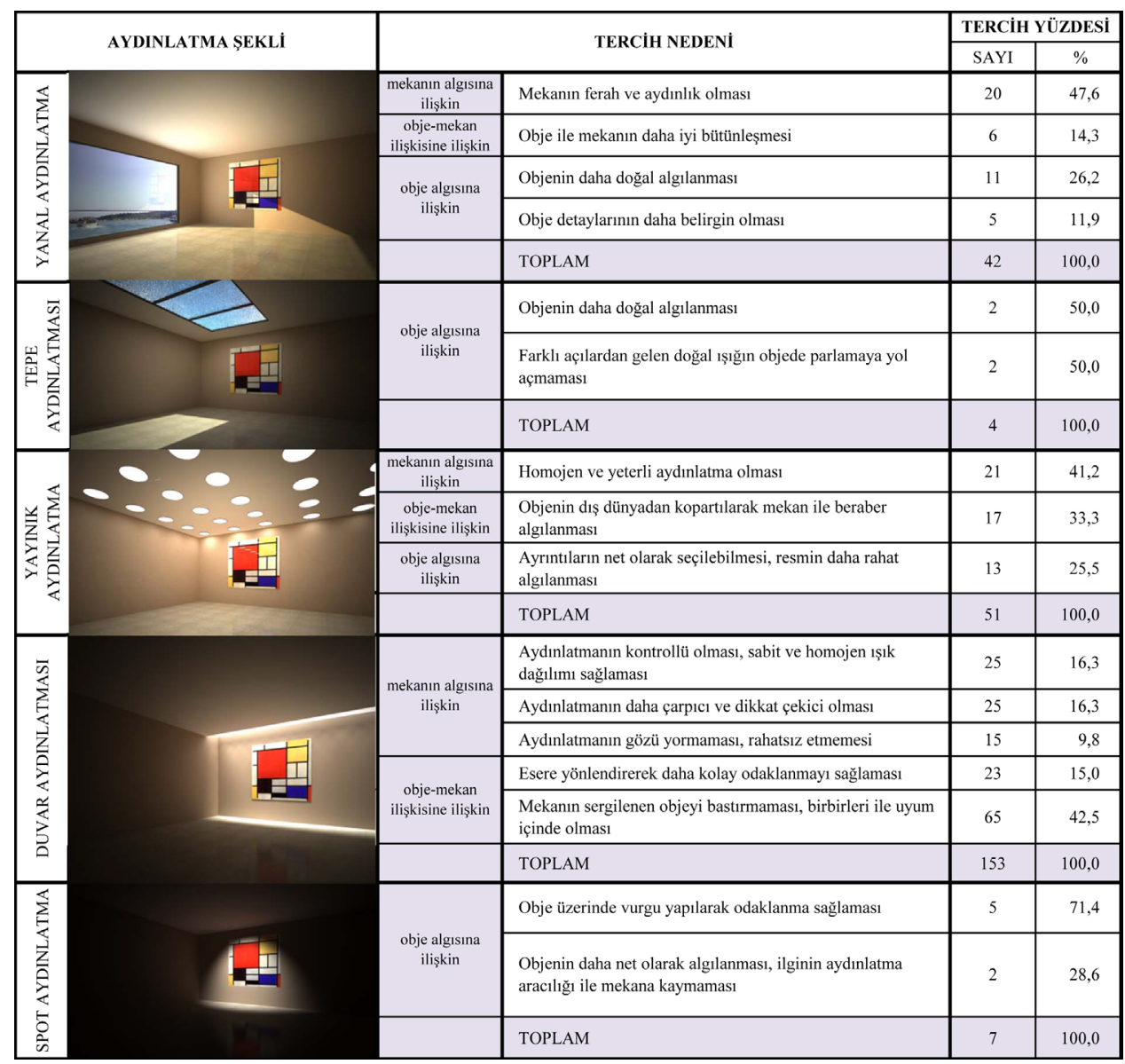

Ankete katılan ziyaretçilerin bütünü dikkate alındığında, iki boyutlu eserlerin aydınlatılmasında en çok duvar aydınlatma biçimi $(\% 59,2)$ tercih edilmiş, bu tercihi sırasıyla yayınık aydınlatma $\% 20$ ,4), yanal aydınlatma $(\% 15,8)$, spot aydınlatma $(\% 2,7)$ ve tepe aydınlatmasi $(\% 1,2)$ izlemiștir. Üç boyutlu eserlerin aydınlatılmasında doğal ve yapay aydınlatma türleri arasında daha eşdeğer bir dağılım gerçekleşirken, iki boyutlu eserlerin sergilenmesinde yapay aydınlatma türü, özellikle de duvar yüzeyini ve duvarda sergilenen iki boyutlu eseri öne çıaran duvar aydınlatma biçimi tercih edilmiştir (Tablo 3).

\section{Aydınlatma tercihlerini etkileyen nedenler}

Aydınlatma tercihlerini etkileyen nedenlerin sorulduğu açık uçlu sorulara verilen tepkilere içerik analizi uygulanmış ve tepkiler mekân algısı, eser-mekân ilişskisi ve eserin algısı ile ilişkili olmak üzere üç ana kategori altında toplanmıştır. Tercih nedenleri ziyaretçilerin bütünü dikkate alınarak analiz edildiğinde, en çok tercih edilen aydınlatma biçimi olan yayınık aydınlatmanın, ziyaretçiyi "dıș dünyadan koparması ve sergilenen eserin mekân ile beraber algılanmasını kolaylaştırması" nedeni ile tercih edildiği görülmektedir. (\%50). Üç boyutlu eserlerin aydınlatılmasında en çok tercih edilen ikinci aydınlatma türü olan yanal aydınlatmayı tercih eden ziyaretçiler ise tercih nedenlerini, çoğunlukla "mekânın ferah ve aydınlık olması" ile ilişkilendirmektedir (\%52,7). Genel dağılımda daha az tercih edilen aydınlatma biçimlerinden olan tepe aydınlatmasının "eserin doğal algılanmasını sağlaması" (\%45,5), spot aydınlatmanın ise "eserin vermek istediği anlamı ön plana çıkartması" nedenleri ile tercih edildiği tespit edilmiştir (\%52,3) (Tablo 4). 
Ziyaretçiler iki boyutlu eserlerin aydınlatılmasında yanal aydınlatma yöntemini, çoğunlukla "mekânın ferah ve aydınlık olması" (\%47,6), tepe aydınlatması yöntemini ise "eserin daha doğal algılanması" $(\% 50)$ ve "farklı açılardan gelen doğal ışığın eserde parlamaya yol açmaması" (\%50) nedenleri ile tercih etmektedirler. Yapay aydınlatma yöntemlerinden olan yayınık aydınlatmay "homojen ve yeterli ışık sağlaması" (\%41,2), en çok tercih edilen duvar aydınlatma biçimini ise "aydınlatmanın kontrollü, sabit ve homojen 1şık dağılımı sağlaması" (\%16,3) ve "aydınlatmanın daha çarpıcı ve dikkat çekici olması" (\%16,3) nedenleri ile tercih etmektedirler. Tercihler arasinda en az yer tutan spot aydınlatma ise ziyaretçiler tarafından "eser üzerine vurgu yaparak odaklanmayı sağlaması" nedeni ile $(\% 71,4)$ tercih edilmektedir (Tablo 5).

\section{Tartışma ve Sonuç}

$\mathrm{Bu}$ araştırmada aydınlatma biçimlerine göre sergi mekânlarının nasıl algılandığı affektif (duygusal) ve bilişsel boyutlarıyla çözümlenmiş, ziyaretçilerin aydınlatma tercihleri ile bu tercihleri belirleyen nedenler irdelenmiştir. Araştırma sonuçlarına göre aydınlatma türleri ile sergi deneyimini etkileyen affektif mekân algısı arasındaki ilişkinin varlığına ilişkin göstergeler mevcutsa da sorgulanmaya açıktır. Affektif algıyı ölçen anlamsal farklılaşma cetveline verilen tepkilere göre, doğal biçimde aydınlatılan CerModern sanat merkezindeki sergi mekânları, yapay olarak aydınlatılan Arkas Sanat Galerisi'nin sergi mekânlarına göre "daha büyük, daha geniş, daha ferah, daha açık" değerlendirilmiştir. Ancak, iki sergi mekânı arasında aydınlık düzeyi, hoşluk, çekicilik, güzellik, konforluluk açısından önemli bir fark ortaya çıkmamıştır.

Mekânsal algılama ve değerlendirmenin bilişsel boyutu incelendiğinde, CerModern sanat merkezinde yapının en çok fiziksel özelliklerinin, ASM'de ise sergi içeriğinin hafızada yer tuttuğu, dolayısıyla aydınlatma biçiminin bilişsel algıda etkili olabileceği görülmüştür. ASM'de hatırlanan özelliklerin sergi mekânı ve içeriği ile ilgili detaylara yoğunlaşması, olasılıkla yapay aydınlatmanın algıyı eser üzerine odaklaması ile ilişkilendirilebilir.

Kuşkusuz incelenen yapılar ölçek ve mekân örgütlenmesi açısından birbirinden farklı özellikler göstermektedir. CerModern total ve daha büyük bir hacme sahipken, Arkas Sanat Galerisi bölüntülü ve daha küçük bir hacme sahiptir. Bu anlamda ortaya çıkan affektif ve bilişsel alg1 farkının söz konusu karıştırıcı değişkenlerden de etkilenmiş olma olasılı̆̆ını dikkate almak gerekmektedir.

Çalışmada iki ve üç boyutlu eserleri temel alarak hazırlanan tercih ölçeklerinin ziyaretçi/izleyici açısından oldukça anlaşılır olduğu ve anlamlı sonuçlar verdiği gözlenmiştir. Ziyaretçi tercihleri sergilenen eserin düzlemsel ya da üç boyutlu olma durumuna göre farklılaşmıştır. İncelenen sergi mekânlarında, üç boyutlu eserlerin aydınlatılmasında en fazla tercih edilen aydınlatma türleri, doğal ve yapay ışık kaynağı açısından eşdeğer bir dağılıma sahiptir. Üç boyutlu eserlerin sergilenmesinde en çok tercih edilen yapay aydınlatma türü, homojen 1şık dağılımı sağlayan yayınık aydınlatma, en çok tercih edilen doğal aydınlatma türü ise yanal aydınlatmadır. Yayınık aydınlatmayı tercih eden ziyaretçilerin çoğu tercih sebeplerini "sergilenen esere ve sergi mekânına odaklanma sağlaması" ile açıklamaktadır. Yayınık aydınlatma ile benzer oranlarda tercih edilen doğal aydınlatma türevlerinden yanal aydınlatma ise en çok"sergi mekânını ferah ve aydınlık kılması" nedeniyle tercih edilmiştir.

Üç boyutlu eserlerin aydınlatılmasında tercihlerin doğal ve yapay aydınlatma olarak eşit ağırlıkta bölünmesi her iki aydınlatma türünün de görsel ölçekte mekânın bütününün kavranmasını kolaylaştırması ile ilişkili görünmektedir. Üç boyutlu eserler iki boyutlu olanlardan farklı olarak hacmin içinde kavranmaktadır. Bu anlamda ziyaretçilerin önemli bir bölümü aydınlatma tercihi yaparken, eserin algısının yanı sıra ona önemli 
bir altlık oluşturan mekânın algısını da önemsemiş̧lerdir. Üç boyutlu eserlerin aydınlatılmasında kullanıcı açısından doğal ya da yapay sşık türü ayırıcı bir faktör olarak devreye girmemiştir ancak yine de parlama ve soldurma etkisinin önemli olmadığı ya da bu türden etkilerin teknik önlemlerle kontrol edilebildiği üç boyutlu eser sergilerinde, mekân atmosferini ve mekânla kurulan affektif (duygusal) ilişkiyi olumlu yönde geliştiren doğal 1şık bileşeninin kullanılmasının olumlu olacağ düşünülmektedir.

İki boyutlu eserlerin aydınlatılmasında ise ziyaretçiler önemli bir farkla yapay aydınlatma biçimlerinden sırasıyla duvar aydınlatmasını ve yayınık aydınlatmayı tercih etmiştir. En çok tercih edilen duvar aydınlatması, iki boyutlu eseri ve sergilendiği duvar zeminini algılanabilir kılan bir aydınlatma türüdür. Bu anlamda, yalnızca sergilenen eserin aydınlatılmasının değil, ona zemin oluşturan duvarın algılanmasının da önemsendiği dikkati çekmektedir.

Duvar aydınlatmasını tercih edenlerin öne sürdüğü nedenler gözden geçirildiğinde, ziyaretçilerin kontrollü, "sabit ve homojen 1şık dağılımı" ile "aydınlatmanın çarpıcı ve dikkat çekici olması" faktörleri üzerinde yoğunlaştığı görülmektedir. En çok tercih edilen ikinci aydınlatma türü olan yayınık aydınlatma, "homojen ve yeterli 1şık sağlaması" nedeniyle tercih edilmiştir. $\mathrm{Bu}$ anlamda, iki boyutlu eserlerin aydınlatılmasında ziyaretçi açısından odaklanma ve konsantrasyon sağlaması açısından, yapay aydınlatma sistemlerinden duvar aydınlatması ile yayınık aydınlatmanın ideal çözümler olarak öne çıktı̆̆ 1 görülmektedir.

Sonuç olarak, gerçekleştirilen alan çalışması mekân algısının oldukça kompleks ve çok boyutlu olduğunu, karıştırıcı değişkenler kontrol edilemediğinde aydınlatmanın mekân algısına olan etkisinin gözlemlenmesinin zor olduğunu göstermiş̧ir. Aydınlatma düzeyinin mekânın büyüklük-küçüklük, genişlik-darlık, açıklık-kapalılık, ferahlık-kasvetlilik gibi sınır ve büyüklük algısı ile ilişkili olduğu yapılan deneysel araştırmalarla bilinmektedir (İmamoğlu 1975; Durak vd. 2007). Bu anlamda ileride yapılacak araştırmaların, aydınlatmanın sergi mekanının algısına olan etkisini daha sağlıklı gözlemek için çalışmanın ilk bölümünü, sergileme düzeni, mekan büyüklüğü, renk, doku vb. karıştırıcı değişkenler açısından benzer özelliklere sahip örneklerle ya da bu tür değişkenlerin kontrol edildiği alan deneyleriyle yinelemesi önerilebilir. Böylelikle mekânsal deneyimi dikkate alan ve gerçek kullanıcılara ulaşan ancak karıştırıcı değişkenleri kontrol etmede sınırlı kalan alan çalışmaları ile, değişkenleri kontrol eden ancak deneyim bilgisini dışarıda bırakan deneysel çalışmalardan edinilen bilgilerin bütünleştirilmesi ve karşılıklı kontrol edilmesi mümkün olabilecektir.

\section{TEŞEKK $\ddot{U R}$}

Bu çalışma, Dokuz Eylül Üniversitesi BAP Koordinasyon birimi tarafindan desteklenen, 2011.KB.FEN.027 (YL, 201150) numaralı ve "Sergi Mekânlarında Aydınlatma Biçimlerinin Kullanıcı Algısı Üzerindeki Etkileri”" başlıklı yüksek lisans tez projesinin bir bölümünden hazırlanmıştır. Dokuz Eylül Üniversitesi Bilimsel Araştırma Projeleri Koordinasyon birimine ve makalenin gelişmesinde değerli görüş ve önerileriyle katkıda bulunan anonim hakemlere teşekkür ederiz. 


\section{KAYNAKÇA}

Ajmat, R. J., Sandoval, J., Arana Sema, F., Donell B.O, Gor., S. ve Alonso H. 2011. Lighting Design in Museums: Exhibition vs. Preservation. In C.A. Brebbia \& L. Binda (Eds). Structural Repairs and Maintenance of Heritage Architecture XII. WIT Press, pp. 195-206.

Bechtel, R. B. ve Churchman, A. 2002. Handbook of Environmental Psychology. New York: John Wiley\&Sons, Inc.

Bell, P. A., Greene, T. C. ve Fisher J. D., Baum A. 2001 Environmental Psychology (5th Edition). London: Lawrence Erlbaum Associates.

Biner, Paul M., Butler, D. L., Fisher, A. R. \& Westergren, A. J. 1989. An Arousal Optimization Model of Lighting Level Preferences: An Interaction of Social Situation and Task Demands. Environment and Behavior 21, pp. 3-16

Boer, J. B. D. ve Fischer, D. 1978. Interior Lighting. Antwerp: Kluwer Technical Books.

Bonnes, M. ve Secchiaroli, G. 1995. Environmental Psychology: A Psycho-social Introduction. London: Sage Pub.

Boyce, P. R. 1981. Human Factors in Lighting. London Applied Science.

Doğrusoy, İ.T. 2002. Mimari Bir Eleman Olan Pencerelerin/Açılıkların, Insan-Mekân Iliskileri Bağlamında İrdelenmesi: Ofis Mekânları İçin Bi Deneme. Yayımlanmamıs Doktora Tezi. İzmir, Dokuz Eylül Üniversitesi Fen Bilimleri Enstitüsü.

Doğrusoy, İ.T. ve Türeyen, M. 2007. A Field Study on Determination of Preferences for Windows in Office Environments. Building and Environment 42 (10), pp. 3660-3668.

Downs, R. M. ve Stea, D. 1973. Image and Environment. Chicago: Adline.

Durak, A.,Olguntürk, N. C., Yener, C., Güvenc, D., Gürçınar B. 2007. Impact of Lighting Arrangement and Illuminances on Different Impressions of a Room. Building and Environment 42 (10), pp. 3476-3482.

Erbay, M. 2011. Müzelerde Sergileme ve Sunum Tekniklerinin Planlanması. İstanbul: Beta Basım A.Ș.

Flynn, J. E. 1977. A Study of Subjective Responses to Low Energy and Nonuniform Lighting Systems. Lighting Design and Application 7, pp. 6-15.

Gifford, R. 1988. Light, Decor, Arousal, Comfort and Communication. Journal of Environmental Psychology 8, pp. 177-189.

Gifford, R. 2007. Environmental Psychology: Principles and Practice (4th Edition). Canada: Optimal Books.

Heerwagen, J.H. 1990. Affective Functioning "Light Hunger" and Room Brightness Preferences. Environment and Behavior 22, pp. 608-635.

Holahan, J. C. 1982. Environmental Psychology. New York: Random House

Ittelson, W., Proshansky, H., Rivlin, L. ve Winkel, G. 1974 Introduction to Environmental Psychology. New York: Holt, Rinehart and Winston.

İmamoğlu V. 1975. Spaciousness of Interiors: Its Meaning, Measurement and Relationship to Some Architectural Variables. Unpublished Dissertation, StrathclydeUniversity.

Kesner, C.W. 1993. Museum Exhibition Lighting: Visitor Needs and Perceptions of Quality. Journal of
Illuminating Engineering Society 22 (1), pp. 45-54.

Kılıç, D. K. ve Hasirci, D. 2011. Daylighting Concepts for University Libraries and Their Influences on Users' Satisfaction. The Journal of Academic Librarianship 37 (6), pp.471-479.

Knez, I. ve Kers, C. 2000. Effects of Indoor Lighting, Gender and Age on Mood an Cognitive Performance. Environment and Behavior 32(6), pp. 817-831.

Kurtay C., Aybar U., Başkaya A., Aksulu I. 2003. Perception and Analysis of Lighting Criteria's in Museums. Journal of The Faculty of Engineering and Architecture of Gazi University 18 (2), pp. $95-113$.

Küller, R. 1973. Architectural Psychology. In R. Küller (Eds.) Beyond Semantic Measurement: Proceeding Book of the Lund Conference. Straudsburg, 26-19 July Hutchin. Lund: Studentlitteratur, pp. 353-372.

Mahrebian, A. ve Russell, J. 1974. An Approach to Environmental Psychology. Cambridge: MIT Press.

Manav, B. ve Yener, C. 1999. Effects of Different Lighting Arrangements on Space Perception. Architectural Science Review 42 (1), pp. 43-48.

Russell, V. ve Arkkelin, D. 1995. Environmental Psychology: An Interdisiplinary Perspective. New Jersey: PrenticeHall.

Van Erp, T. 2008. The Effects of Lighting Characteristics on Atmosphere Perception. Unpublished manuscript for Philips Research, Eindhoven, Netherlands.

Wineman, J. D. ve Peponis, J. 2009. Constructing Spatial Meaning: Spatial Affordences in Museum Design. Environment and Behavior 42 (1), pp. 86-109.

Winkel, G., Saegert, S. ve Evans, G. W. 2009. An Ecological Perspective on Theory, Methods, and Analysis in Environmental Psychology: Advances and Challenges. Journal of Environmental Psychology. 29, pp. 318-328.

URL 1: [çevrimiçi]. Erişim yeri: http://www.arkassanatmerkezi.com/contents/7/images/ thumbs/120910220101_hakkimizda.jpg [Erişim tarihi: 12 Nis 2015]. 